\title{
Carbon Dioxide Emissions: A Multivariate Analysis HJ-Biplot, Clustering Biplot and Clustering Disjoint Biplot
}

\author{
Pilacuan Bonete Luis ${ }^{1,2}$, Galindo Villardon Purificación ${ }^{1}$ \\ ${ }^{1}$ University of Salamanca, Spain \\ i_luis.pilacuanb@usal.es; pgalindo@usal.es \\ ${ }^{2}$ University of Guayaquil, Ecuador \\ luis.pilacuanb@ug.edu.ec
}

\begin{abstract}
This document studies graphically, through cluster groups, 17 countries in Europe and South America, generating an order with respect to different variables of public spending, education, environmental, public security, this in order to know the relationship they have with the Carbon Dioxide emissions variable, and generate a multivariate appreciation, using a comparison between the HJBiplot methods of the MulBiplot software, Clustering Biplot and Clustering Disjoint Biplot, using the RStudio software.

The clusters obtained allow us to interpret in a broader context the relationship and variability of each country in relation to a set of variables, and to know the homogeneity between countries. In conclusion, using the three grouping methods with certain similarities since all three use the HJ-Biplot within their processes, but differ in others, it was possible to observe how the carbon dioxide emissions, considered as one of the gases causing the greenhouse effect maintains a positive relationship with the economic growth of the countries represented by the GDP per capita, since in the three groups by cluster both variables remain always related, while the variable of Expenditure in Research presents a positive relationship also with respect to these variables, however in the CDBiplot is part of a different factorial axis than the other two variables.
\end{abstract}

Keywords: HJ-Biplot, Clustering Biplot, Clustering Disjoint HJ-Biplot, Carbon Dioxide.

\section{Introduction}

Carbon dioxide (CO2), It is an odorless and colorless gas that is released in the respiration, in the combustions and in some fermentations, considered as part of the greenhouse gases by the "Food and Agriculture Organization" (FAO) [1], around this chemical compound, different studies have been generated, such as predictions of emissions [2] [3], counts of this compound [4], among other studies. FAO carries out different analyzes in relation to greenhouse gases [5] [1], In a study generated in China, the relationship between the Gross Domestic Product was reviewed (GDP) and CO2 emissions [6], where it was observed how the growth of the GDP was related to the emissions of the chemical compound.

Many authors use for the representation of multivariate results, as well as for a better interpretation, the clustering tools of the results by means of cluster, which allows to classify the individuals in study according to similarity or in relatively homogeneous groups [7], multiple analyzes have been made in different fields of science using various classification methods, among which we have HJ-Biplot [8], Discriminant Analysis with Regularization Approach [9], K-means [10], MapReduce [11], FCM, Fuzzy C-means Clustering algorithm [12], Decomposition of singular values [13], among many other studies.

The HJ-Biplot method proposed by Galindo [14], allows to represent the coordinates in the same system of factorial axes, both rows and columns, in the data matrices, allowing a greater interpretation compared to a correspondence analysis or factorial analysis [8]. The Clustering Disjoint HJ-Biplot (CDBiplot) [15], it allows the visualization of the data in an underlying way, by means of a classification of the groups in a reduced space, generating factorial axes disjuncts, where each of the variables only contributes to the construction of a factorial axis, these results are visualized with the use of the HJBiplot method. The Clustering Biplot (CBiplot) allows to represent the data with group structure, obtaining a representation of both individuals and variables in the same representation space and maximizing the separation between clusters using the distance of Mahalanobis. Unlike a HJ-Biplot, the CBiplot approximates the starting matrix X by means of a matrix that contains the centroids instead of the original values, several authors have carried out several works that have been 
characterized by the use of centroids for the calculation of the different cluster groups, with different algorithms [16][17][18][19].

The present study seeks to relate 17 countries, 3 from South America and 14 from Europe divided into 4 regions, to understand through the analysis of grouping methodologies the contribution of 42 educational variables, public and private spending, environmental, mortality, among others, with the variable of carbon dioxide gas emissions per capita (Ver Anexo).

\section{Methodology}

For the analysis of the interactions and obtaining of the clusters, 2015 data from the United Nations Data Retieval System [20] were reviewed, from 17 countries that had complete information on the study variables, which were grouped into regions according to their geographical location: 1.- Central Europe; 2.- North of Europe; 3.- South of Europe; 4.- South America.

Table 1: List of countries.

\begin{tabular}{|c|l|c|l|}
\hline Regions & \multicolumn{1}{|c|}{ Country } & Regions & \multicolumn{1}{c|}{ Country } \\
\hline 1 & $\begin{array}{l}\text { Slovakia, Belgium, Romania, } \\
\text { Slovenia, Poland y France }\end{array}$ & 3 & $\begin{array}{l}\text { Spain, Bulgaria, Portugal } \\
\text { y Serbia }\end{array}$ \\
\hline 2 & Estonia, Latvia, Lithuania y Ireland & 4 & Brazil, Chile y Ecuador \\
\hline
\end{tabular}

\subsection{HJ-Biplot}

As briefly explained, the HJ-Biplot is a multivariate graphic representation in the same reference system with maximum representation quality of the rows and columns markers, which allows to study the row-column relationships through factors, as in the case of the Factorial correspondence Analysis, or through measures or indices to know the relative contributions of the factor to the element and from the element to the factor, for the analysis of the data the MulBiplot software was used [21], which allows to carry out multiple studies related to the aforementioned analyzes.

$$
\begin{array}{|cc|}
\mathrm{X}^{2}=\mathrm{UDV}^{\mathrm{T}} & \mathrm{J}=\mathrm{U} \mathrm{D} \\
1 & \mathrm{H}=\mathrm{VD} \\
\hline
\end{array}
$$

Fig. 1: Formulation scheme of the HJ-Biplot.

\subsection{Clustering Biplot}

The CBiplot, as indicated above, approximates the starting matrix $\mathrm{X}$ by means of a matrix that contains the centroids instead of the original values, that is, it reproduces the centroid matrix from the coordinates, taking the distance between the clusters with the Mahalanobis model. For this, $\mathrm{K}$ interactions are generated with a stop criterion given a certain level of tolerance (tol), where the $\mathrm{F}_{\mathrm{K}}$ is searched for which $\left|\mathrm{F}_{\mathrm{K}}-\mathrm{F}_{\mathrm{K}-1}\right|<=$ tol, in order to maximize the function $\mathrm{F}_{0}=\left\|\mathrm{U}_{0} \mathrm{~A}_{0}\right\|^{2}$

$$
\begin{aligned}
& \left\|\mid \overline{U A} \Lambda^{-1} B^{T}\right\|^{2}=\operatorname{tr}\left[\left(\overline{U A} \Lambda^{-1} B^{T}\right)\left(\overline{U A} \Lambda^{-1} B^{T}\right)^{T}\right]=\operatorname{tr}\left[\left(U \bar{X} B \Lambda^{-2} B^{T}\right)\left(U \bar{X} B \Lambda^{-2} B^{T}\right)^{T}\right]= \\
& \operatorname{tr}\left[\left(U \bar{X} B \Lambda^{-1}\right) \Lambda^{-1} B^{T} B \Lambda^{-1}\left(U \bar{X} B \Lambda^{-1}\right)^{T}\right]=\operatorname{tr}\left[\left(U \bar{X} B \Lambda^{-1}\right)\left(U \bar{X} B \Lambda^{-1}\right)^{T}\right]=\|U \bar{A}\| \|^{2}=F
\end{aligned}
$$

Fig. 2: Distance between clusters.

Once the $F_{k}$ is found that meets the stop criterion or the number of a priori interactions is reached, the process is stopped and the resulting matrices are taken as a result, it is necessary to carry out the interaction process several times in order not to fall local maximum, a maximum number of iterations of 500 is recommended. 


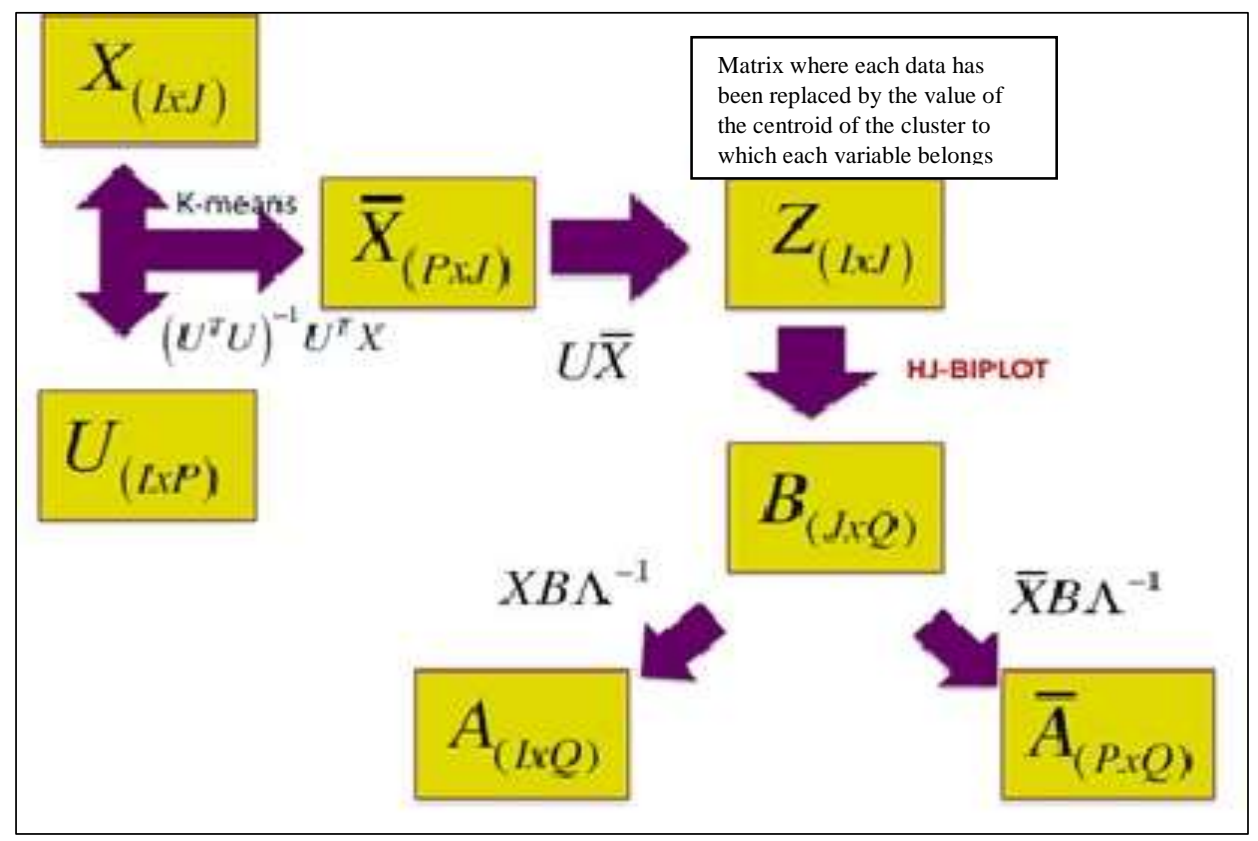

Fig. 3: Scheme of the Biplot Clustering.

For the CBiplot analysis, the data was entered into the RStudio software, so that through the available package biplotbookGUI [22] the data are analyzed in the R language, separating the data into groups a priori (regions), making 1000 repetitions of the algorithm.

\subsection{Clustering Disjoint Biplot}

This method allows obtaining on the one hand the components that maximize the distance between the centroids of the $\mathrm{N}$ cluster of the I object, as well as allowing to observe the $\mathrm{Q}$ components found that are only conformed by the contributions of one of the $\mathrm{J}$ variables analyzed. Like the CBiplot, this is an interactive process that seeks to maximize the algorithm and optimization process of each object belonging to each cluster. In this method the matrix B is built column by column performing a HJ-Biplot analysis on each $\mathrm{Q}$ and where $\mathrm{V}$ is a location matrix of the $\mathrm{J}$ variables in the component $\mathrm{Q}$, it is a binary matrix where the sum of the elements of each row is one, in this matrix for each row the non-null element is positioned in all the columns and the rest is calculated with that matrix in order to calculate the values of the objective function.

$$
\begin{aligned}
& \left\|U \bar{A} \Lambda^{-1} B^{t}\right\|^{2}=\operatorname{tr}\left[\left(U \bar{A} \Lambda^{-1} B^{T}\right)\left(U \bar{A} \Lambda^{-1} B^{T}\right)^{T}\right]=\operatorname{tr}\left[\left(U \bar{X} B \Lambda^{-2} B^{T}\right)\left(U \bar{X} B \Lambda^{-2} B^{T}\right)^{T}\right]= \\
& \operatorname{tr}\left[\left(U \bar{X} B \Lambda^{-1}\right) \Lambda^{-1} B^{T} B \Lambda^{-1}\left(U \bar{X} B \Lambda^{-1}\right)^{T}\right]=\operatorname{tr}\left[\left(U \bar{X} B \Lambda^{-1}\right)\left(U \bar{X} B \Lambda^{-1}\right)^{T}\right]=\|U \bar{U}\|^{2}
\end{aligned}
$$

Fig. 4: Distance between clusters CDBiplot.

The process of iterations stops once the maximum number of a priori iterations has been reached, 1000 iterations of 500 repetitions of the algorithm are recommended, and these matrices are taken as a result. 


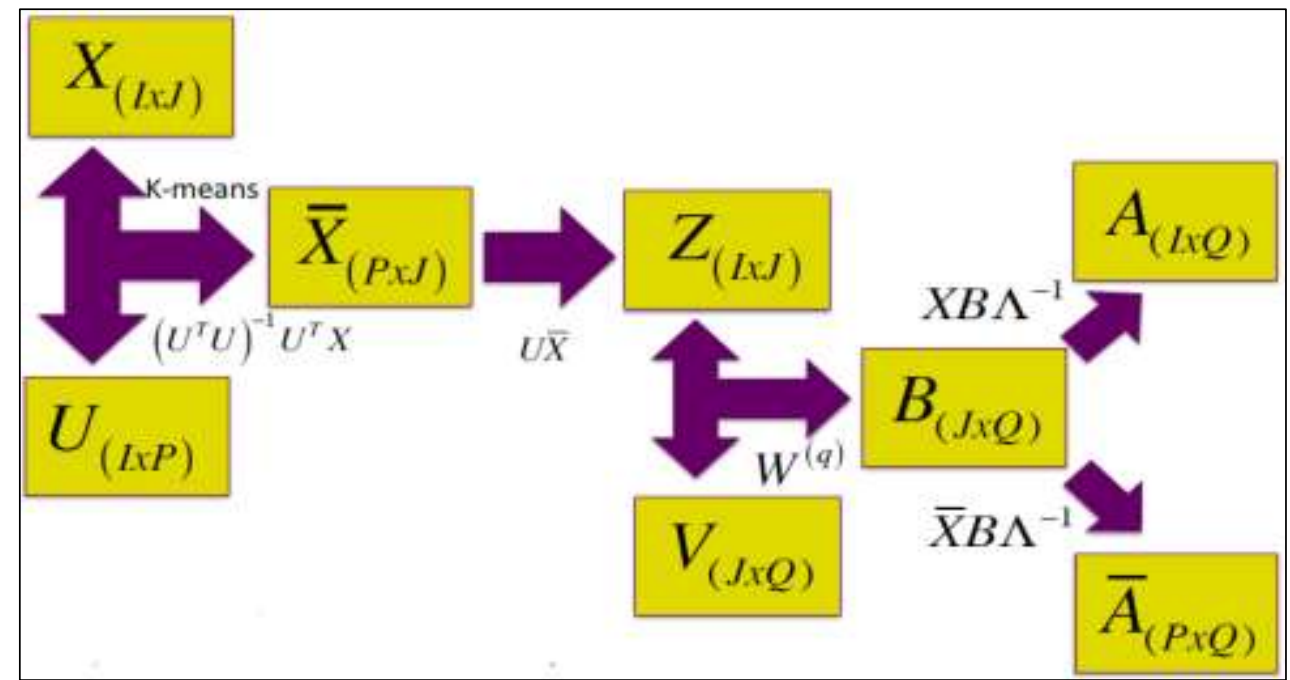

Fig. 5: Diagram of Clustering Disjoint Biplot.

The CDBiplot was analyzed using the available package biplotbookGUI [22] in the R language, separating the data into groups a priori (regions), performing 1000 repetitions of the algorithm with 500 repetitions each iteration, obtaining 4 cluster as a result.

\section{Results}

When analyzing the results obtained in the MulBiplot software, once the data were reviewed and the matrix of the individuals and the variables was revised, the columns were standardized and a decomposition of singular values was made by selecting a 2-component dimensionality, to obtain the results shown in figure 6 .

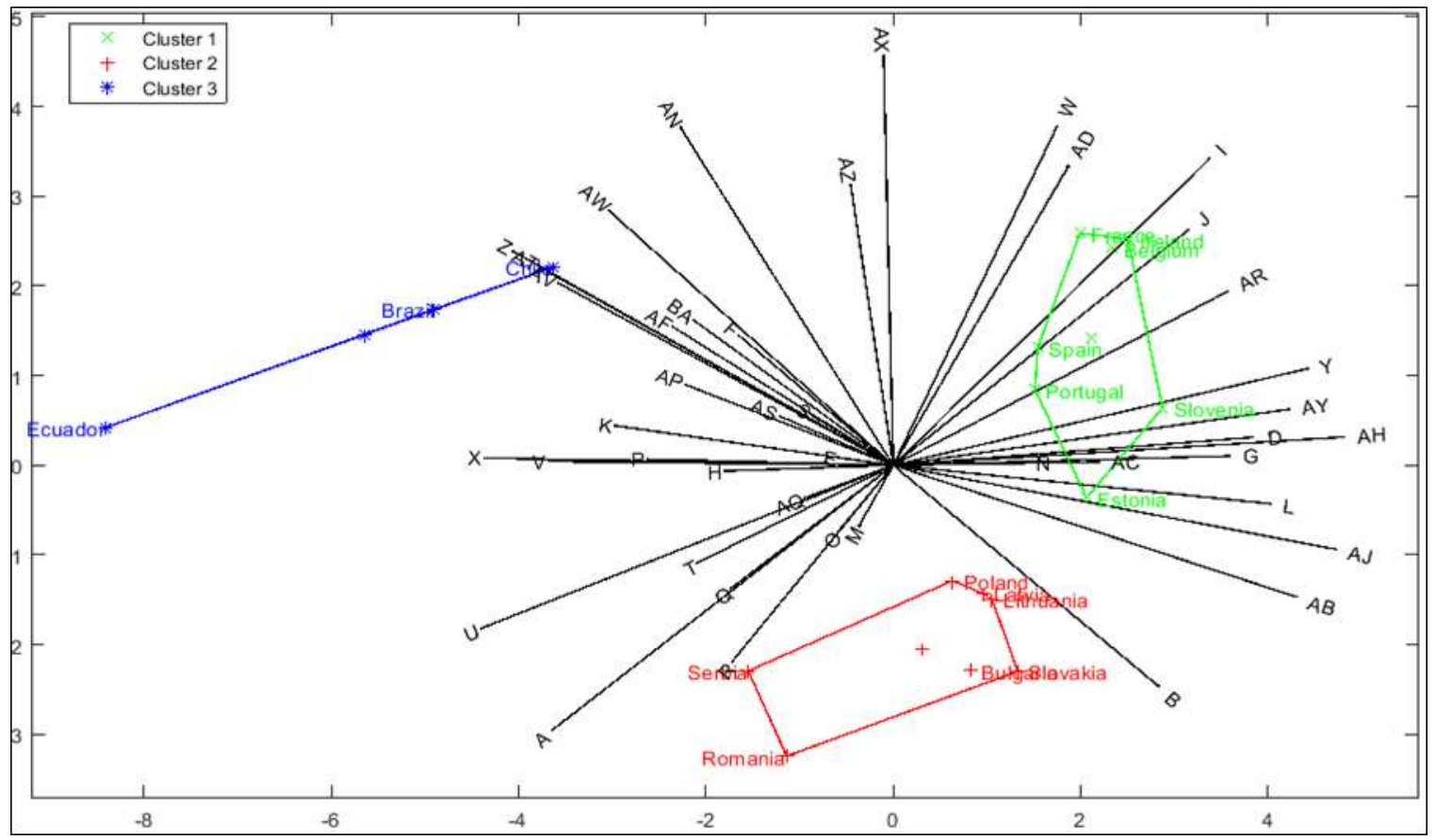

Fig. 6: Cluster HJ- Biplot in MulBiplot. 
It clearly shows three clusters, formed by: Cluster 1 (green): France, Portugal, Spain, Estonia, Slovenia, Ireland, Belgium; Cluster 2 (red): Serbia, Romania, Bulgaria, Slovakia, Poland, Lithuania, Latvia; Cluster 3 (blue): Chile, Brazil, and Ecuador.

In Cluster 1, it is observed how the variable D (carbon dioxide emissions per capita) has a high positive impact with these countries, that is, a positive correlation, as well as with the variables AD (Public Expenditure on Education), J ( Expenditure on Research and Development), AH (number of Researchers), L (Terrestrial Biodiversity Sites), AY (Tourist Income), AR (\% of National Theft), Y (Internet Use), W (Life Expectancy at born), I (GDP per capita). In Cluster 2, there is a positive relationship between variables B (\% of agriculture, hunting, fishing and forestry), $\mathrm{R}$ (Industrial Production of Machinery), A (\% of arable land) and values close to the average with respect to the variable D. Cluster 3 has variables that have a negative incidence, that is, an inverse relationship with the Carbon Dioxide Emissions variable, such as the variables X (Maternal Mortality), Z (\% of Population = < 14 years old), AV (\# Threatened Animals), AT (\# of Endangered Plants).

In a joint observation you can see how the variables of Public Expenditure and Environmental Indicators are correlated among the three clusters, it can also be seen how in the Cluster 1 Countries, the Per capita Carbon Dioxide Emissions have a positive relationship with Public Expenditure in Research and Development with a covariation angle where it is observed that they present a high degree of relationship between both and that the Countries of this cluster have values above the average in relation to those of the other two clusters, that is to say You can see how spending on research, higher education, the value of GDP per capita have a direct relationship with the value of carbon dioxide emissions, but also a high number of important sites for terrestrial biodiversity, as well as a rotation of very high tourists, these variables have an inverse relationship with the number of animals and plants in threat, and a low maternal mortality.

In the RStudio software, with the help of the biplotbookGUI package, the data were analyzed by performing 1000 iterations of the algorithm, selecting 3 clusters, obtaining as a result the graph shown in figure 7 of the Clustering Biplot analysis.

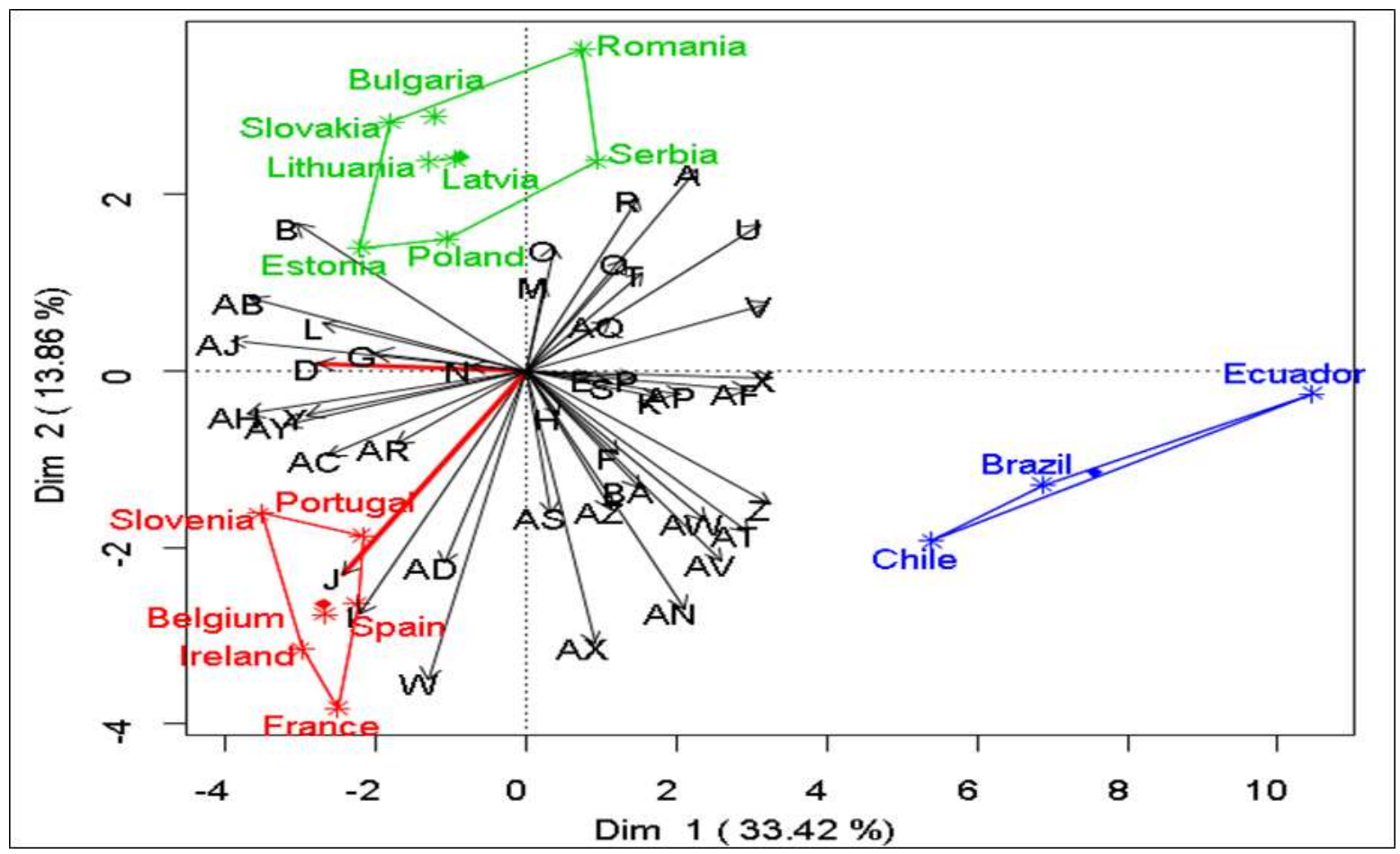

Fig. 7: Clustering Biplot in RStudio.

As in the HJ-Biplot, 3 clusters were obtained, Cluster 1: France, Portugal, Spain, Slovenia, Ireland, Belgium; Cluster 2: Serbia, Romania, Bulgaria, Slovakia, Poland, Lithuania, Latvia, Estonia; Cluster 3: Chile, Brazil, and Ecuador. Presenting a variation in relation to Estonia, who went from Cluster 1 to Cluster 2; the variables in Cluster 3 maintain their relation in comparison to the HJ-Biplot, in Cluster 1, the Public Expenditure in Research and Development is positively related to the per capita emissions of Carbon Dioxide, there it is observed that this relationship is maintained in comparison to HJ-Biplot 
but the angle between variables decreased and the Countries of both Cluster 1 and Cluster 2 stay away from Variable D (Carbon Dioxide Emissions).

It is observed that Variable D, maintains a positive relationship with the variables I (GDP per capita), G (Expenditure in High School education) and AJ (\% of Female Researchers), it is also observed how a negative relationship with the AP variable is maintained. (\# of students enrolled in High School Education).

The same package was used in RStudio for the analysis of the data using the CDBiplot algorithm, the data were entered into R, separating the data into groups a priori (regions), the analysis was performed with the R Package of CDBiplot (Data, region), performing 1000 iterations and 500 repetitions of each iteration of the algorithm, selecting 4 clusters, obtaining as a result the graph of figure 8.

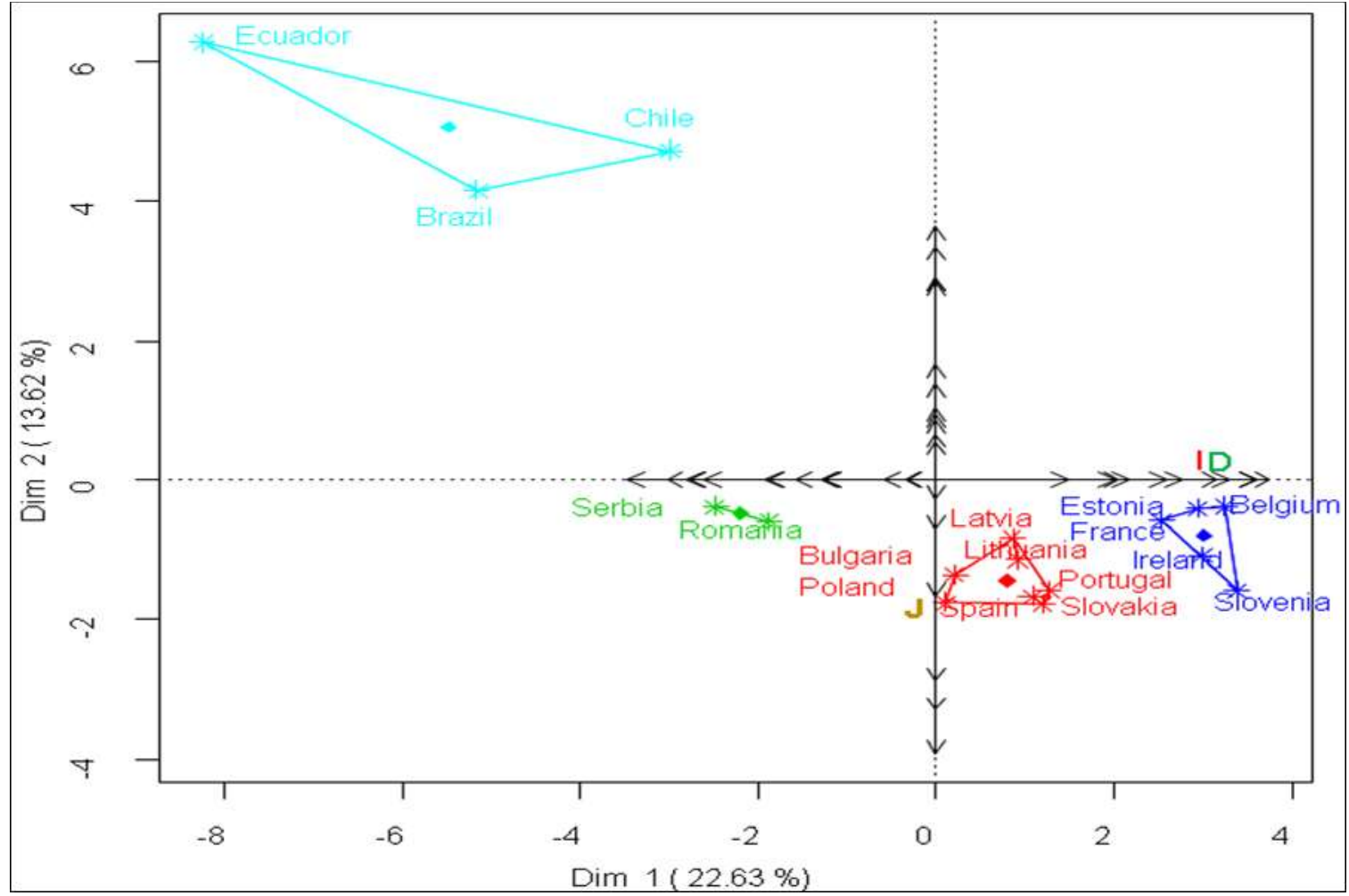

Fig. 8: Clustering Disjoint Biplot in RStudio.

The analysis of the CDBiplot, resulted in four clusters formed by the following countries: Cluster 1: France, Slovenia, Ireland, Belgium, Estonia; Cluster 2: Bulgaria, Slovakia, Poland, Lithuania, Latvia, Portugal, Spain; Cluster 3: Chile, Brazil, and Ecuador y Cluster 4: Serbia, Romania. It can be seen that, in relation to the previous methods, there was a variation in relation to Spain and Portugal, who went from cluster 1 to cluster 2, a new cluster was created consisting of Serbia and Romania; while Cluster 3 is maintained with Chile, Brazil and Ecuador.

With this method we can observe how the variable D (Carbon dioxide emissions per capita) is in the disjunct axis of the abscissa together with the variable I (GDP per capita) and with a high contribution with the countries that make up the Cluster 1 especially with Belgium, while the variable $\mathbf{J}$ (Expenditure on research and development) presents a high contribution to the vertical axis or ordinates, especially with the countries of Bulgaria, Poland, Spain that make up Cluster 2.

It can be seen how the first factorial axis separates cluster 3 formed by the South American countries from the rest of the Cluster made up of the countries of the European continent. And how the second factorial axis separates cluster 3 and 4 from clusters 1 and 2.

\section{Conclusion}

As in previous studies [6], where it is observed that through the use of non-linear mechanisms a positive relationship of GDP and Carbon Dioxide emissions was found in the eastern regions of China due to the economic change after 1995, and 
a slightly negative relationship in the central regions and Western due to the fact that economic change occurred approximately in 2005 .

In this study using three grouping methods with certain similarities since all three use the HJ-Biplot within their processes, but differ in others, it was possible to observe how the carbon dioxide emissions, considered as one of the causing gases of the greenhouse effect maintains a positive relationship with the economic growth of the countries, since in the three groups by cluster both variables always remain correlated, while the variable of Expenditure in Research presents a positive relationship also with respect to these variables, however in the CDBiplot is part of a different factorial axis than the other two variables.

\section{Discussion}

It can be seen how carbon dioxide emissions are positively related to industrialized countries where high investment in development and strong economic growth are generated, although the analyzes carried out are with information published in 2015, it is necessary that countries and cities manage updated metrics in order to carry out public policies that allow the sustainable economic growth of cities and their respective countries.

The mathematical methods applied in the calculations present a different way of obtaining the relationships of variability and clustering between variables and individuals, however, the three methods present similar results in relation to carbon dioxide emissions, which allows us to visualize Through statistical information such as the growth of countries influences $\mathrm{CO} 2$ emissions, future work could express a prediction by clustering the performance of countries according to current policies and data of governments.

\section{References}

[1] Fao, Estimation of greenhouse gas emissions in agriculture. Roma, 2015.

[2] X. Zhao and D. Du, "Forecasting carbon dioxide emissions," J. Environ. Manage., vol. 160, pp. 39-44, Sep. 2015.

[3] R. C. Kafle, K. P. Pokhrel, N. Khanal, and C. P. Tsokos, "Differential equation model of carbon dioxide emission using functional linear regression,” J. Appl. Stat., vol. 46, no. 7, pp. 1246-1259, May 2019.

[4] G. Marland, T. Buchholz, and T. Kowalczyk, “Accounting for Carbon Dioxide Emissions,” J. Ind. Ecol., vol. 17, no. 3, pp. 340-342, Jun. 2013.

[5] FAO, "Emisiones de Gases de Efecto Invernadero de la Agricultura, la Silvicultura y otros usos de la tierra," 2014.

[6] Y. Nie, Q. Li, E. Wang, and T. Zhang, "Study of the nonlinear relations between economic growth and carbon dioxide emissions in the Eastern, Central and Western regions of China," J. Clean. Prod., vol. 219, pp. 713-722, May 2019.

[7] W. Pedrycz, Knowledge-based clustering : from data to information granules. Wiley, 2005.

[8] A. Díaz-Faes, A. A. Díaz-Faes, B. González-Albo, M. P. Galindo, and M. Bordons, "HJ-Biplot como herramienta de inspección de matrices de datos bibliométricos," Rev. española Doc. Científica, vol. 36, no. 1, p. e001, Mar. 2013.

[9] G. Celeux, C. Maugis-Rabusseau, and M. Sedki, "Variable selection in model-based clustering and discriminant analysis with a regularization approach," Adv. Data Anal. Classif., vol. 13, no. 1, pp. 259-278, Mar. 2019.

[10] W. Sun, J. Wang, and Y. Fang, "Regularized k-means clustering of high-dimensional data and its asymptotic consistency," Electron. J. Stat., vol. 6, no. 0, pp. 148-167, 2012.

[11] A. Ene, S. Im, and B. Moseley, "Fast Clustering using MapReduce," pp. 1-20, 2011.

[12] J. C. Bezdek, R. Ehrlich, and W. Full, "FCM: The fuzzy c-means clustering algorithm," Comput. Geosci., vol. 10, no. 2-3, pp. 191-203, Jan. 1984.

[13] V. Castelli and A. Thomasian, "CSVD : Clustering and Singular Value Decomposi- Dimensional Spaces CSVD : Clustering and Singular Value Decomposition for Approximate Similarity Searches in High," Knowl. Data Eng. IEEE Trans., vol. 15, no. 3, 2000.

[14] M. P. Galindo, "Una alternativa de representacion simultanea: HJ-Biplot," Qtlest, vol. 10, no. 1, pp. 13-13, 1986.

[15] A. B. Nieto-Librero, C. Sierra, M. P. Vicente-Galindo, O. Ruíz-Barzola, and M. P. Galindo-Villardón, "Clustering Disjoint HJ-Biplot: A new tool for identifying pollution patterns in geochemical studies," Chemosphere, vol. 176, pp. 389-396, Jun. 2017.

[16] H. Yan, L. Wang, and Y. Lu, "Identifying cluster centroids from decision graph automatically using a statistical 
outlier detection method," Neurocomputing, vol. 329, pp. 348-358, Feb. 2019.

[17] A. Naik, S. C. Satapathy, and K. Parvathi, "Improvement of Initial Cluster Center of C-means using Teaching Learning based Optimization," Procedia Technol., vol. 6, pp. 428-435, 2012.

[18] M. Motwani, N. Arora, and A. Gupta, "A Study on Initial Centroids Selection for Partitional Clustering Algorithms," 2019, pp. 211-220.

[19] A. Sarmiento, I. Fondón, I. Durán-Díaz, and S. Cruces, "Centroid-Based Clustering with $\alpha \beta$-Divergences," Entropy, vol. 21, no. 2, p. 196, Feb. 2019.

[20] United Nations Statistics Division, "UNdata.” [Online]. Available: http://data.un.org/

[21] José Luis Vicente Villardón, "MultBiplot / Análisis Multivariado Biplot.” Available:

http://biplot.usal.es/multbiplot/documentation/

[22] P. G. V. Nieto Ana Belen, "CRAN - Paquete biplotbootGUI," 2015. [Online]. Available: https://cran.rproject.org/web/packages/biplotbootGUI/

\begin{tabular}{|c|c|c|}
\hline \multicolumn{3}{|c|}{$\begin{array}{l}\text { ANNEXED } \\
\text { LIST OF VARIABLES }\end{array}$} \\
\hline Name Variables & Code & Variable Names Spanish \\
\hline $\begin{array}{c}\text { Agriculture, hunting, forestry and fishing (\% of } \\
\text { gross value added) }\end{array}$ & A & $\begin{array}{l}\text { Agricultura, caza, silvicultura y pesca (\% del valor } \\
\text { agregado bruto) }\end{array}$ \\
\hline Arable land (\% of total land area) & B & Tierra arable (\% del área total de la tierra) \\
\hline $\begin{array}{l}\text { Emissions per capita (metric tons of carbon } \\
\text { dioxide) }\end{array}$ & D & $\begin{array}{l}\text { Emisiones per cápita (toneladas métricas de dióxido } \\
\qquad \text { de carbono) }\end{array}$ \\
\hline $\begin{array}{l}\text { Expenditure by level of education: pre-primary } \\
\text { (as \% of government expenditure) }\end{array}$ & $\mathbf{E}$ & $\begin{array}{l}\text { Gastos por nivel de educación: preescolar (como\% del } \\
\text { gasto público) }\end{array}$ \\
\hline $\begin{array}{l}\text { Expenditure by level of education: primary (as \% } \\
\text { of government expenditure) }\end{array}$ & $\mathbf{F}$ & $\begin{array}{l}\text { Gasto por nivel de educación: primaria (como\% del } \\
\text { gasto público) }\end{array}$ \\
\hline $\begin{array}{l}\text { Expenditure by level of education: secondary (as } \\
\qquad \% \text { of government expenditure) }\end{array}$ & G & $\begin{array}{l}\text { Gasto por nivel de educación: secundario (como\% del } \\
\text { gasto público) }\end{array}$ \\
\hline $\begin{array}{l}\text { Expenditure by level of education: tertiary (as \% } \\
\text { of government expenditure) }\end{array}$ & H & $\begin{array}{l}\text { Gasto por nivel de educación: terciario (como\% del } \\
\text { gasto gubernamental) }\end{array}$ \\
\hline GDP per capita (US dollars) & $\mathbf{I}$ & PIB per cápita (miles dólares estadounidenses) \\
\hline $\begin{array}{c}\text { Gross domestic expenditure on R \& D: as a } \\
\text { percentage of GDP (\%) }\end{array}$ & J & $\begin{array}{c}\text { Gasto interno bruto en I + D: como porcentaje del PIB } \\
(\%)\end{array}$ \\
\hline $\begin{array}{l}\text { Gross domestic expenditure on R \& D: Higher } \\
\text { education (\%) }\end{array}$ & K & Gasto interno bruto en I + D: educación superior (\%) \\
\hline $\begin{array}{l}\text { Important sites for terrestrial biodiversity } \\
\text { protected (\% of total sites protected) }\end{array}$ & $\mathbf{L}$ & $\begin{array}{l}\text { Sitios importantes para la biodiversidad terrestre } \\
\text { protegidos (\% del total de sitios protegidos) }\end{array}$ \\
\hline $\begin{array}{l}\text { Index of industrial production: Basic metals } \\
\text { (Index base: } 2005=100)\end{array}$ & M & $\begin{array}{l}\text { Índice de producción industrial: Metales básicos } \\
\text { (Índice base: } 2005=100 \text { ) }\end{array}$ \\
\hline $\begin{array}{l}\text { Index of industrial production: Chemicals, } \\
\text { petroleum, rubber and plastic products (Index } \\
\text { base: } 2005=100 \text { ) }\end{array}$ & $\mathbf{N}$ & $\begin{array}{l}\text { Índice de producción industrial: productos químicos, } \\
\text { petróleo, caucho y productos plásticos (base del } \\
\text { índice: } 2005=100 \text { ) }\end{array}$ \\
\hline $\begin{array}{l}\text { Index of industrial production: Electricity, gas, } \\
\text { steam (Index base: } 2005=100 \text { ) }\end{array}$ & 0 & $\begin{array}{l}\text { Índice de producción industrial: electricidad, gas, } \\
\text { vapor (Índice base: } 2005=100 \text { ) }\end{array}$ \\
\hline
\end{tabular}




\begin{tabular}{|c|c|c|}
\hline $\begin{array}{l}\text { Index of industrial production: Food, beverages } \\
\text { and tobacco (Index base: } 2005=100 \text { ) }\end{array}$ & $\mathbf{P}$ & $\begin{array}{l}\text { Índice de producción industrial: alimentos, bebidas y } \\
\text { tabaco (Índice base: } 2005=100 \text { ) }\end{array}$ \\
\hline $\begin{array}{l}\text { Index of industrial production: Manufacturing } \\
\text { (Index base: } 2005=100)\end{array}$ & $\mathbf{Q}$ & $\begin{array}{l}\text { Índice de producción industrial: Fabricación (Índice } \\
\text { base: } 2005=100 \text { ) }\end{array}$ \\
\hline $\begin{array}{l}\text { Index of industrial production: Metal products } \\
\text { and machinery (Index Base: } 2005=100)\end{array}$ & $\mathbf{R}$ & $\begin{array}{l}\text { Índice de producción industrial: productos metálicos y } \\
\text { maquinaria (Índice base: } 2005=100 \text { ) }\end{array}$ \\
\hline $\begin{array}{l}\text { Index of industrial production: Mining (Index } \\
\text { base: } 2005=100 \text { ) }\end{array}$ & $\mathbf{S}$ & $\begin{array}{l}\text { Índice de producción industrial: Minería (Índice base: } \\
\qquad 2005=100 \text { ) }\end{array}$ \\
\hline $\begin{array}{l}\text { Index of industrial production: Textiles, wearing } \\
\text { apparel, leather, footwear (Index base: } \\
\qquad 2005=100)\end{array}$ & $\mathbf{T}$ & $\begin{array}{l}\text { Índice de producción industrial: textiles, prendas de } \\
\text { vestir, cuero, calzado (Índice base: } 2005=100 \text { ) }\end{array}$ \\
\hline $\begin{array}{l}\text { Infant mortality for both sexes (per 1,000 live } \\
\text { births) }\end{array}$ & $\mathbf{U}$ & $\begin{array}{l}\text { Mortalidad infantil por ambos sexos (por cada } 1.000 \\
\text { nacidos vivos) }\end{array}$ \\
\hline Name Variables & Code & Variable Names Spanish \\
\hline Intentional homicide rates per 100,000 & $\mathbf{v}$ & Tasas de homicidio intencional por 100,000 \\
\hline Life expectancy at birth for both sexes (years) & w & Esperanza de vida al nacer para ambos sexos (años) \\
\hline $\begin{array}{l}\text { Maternal mortality ratio (deaths per } 100,000 \\
\text { population) }\end{array}$ & $\mathbf{x}$ & $\begin{array}{l}\text { Ratio de mortalidad materna (defunciones por } \\
\qquad 100.000 \text { habitantes) }\end{array}$ \\
\hline Percentage of individuals using the internet & $\mathbf{Y}$ & Porcentaje de personas que utilizan internet. \\
\hline Population aged 0 to 14 years old (percentage) & $\mathbf{Z}$ & Población de 0 a 14 años (porcentaje) \\
\hline Population aged $60+$ years old (percentage) & AB & Población de 60 años o más (porcentaje) \\
\hline Population density & AC & Densidad de población \\
\hline Public expenditure on education (\% of GDP) & AD & Gasto público en educación (\% del PIB) \\
\hline $\begin{array}{l}\text { Public expenditure on education (\% of } \\
\text { government expenditure) }\end{array}$ & AF & Gasto público en educación (\% del gasto público) \\
\hline $\begin{array}{l}\text { R \& D personnel: Researchers - total (number in } \\
\text { full-time equivalent population total) }\end{array}$ & $\mathbf{A H}$ & $\begin{array}{l}\text { Personal de I + D: Investigadores - total (número en } \\
\text { equivalente a tiempo completo en porcentaje de la } \\
\text { población total) }\end{array}$ \\
\hline $\begin{array}{l}\text { R \& D personnel: Researchers - women (number } \\
\text { in full-time equivalent population total) }\end{array}$ & AJ & $\begin{array}{l}\text { Personal de I + D: Investigadores - mujeres (número } \\
\text { equivalente a tiempo completo en porcentaje de la } \\
\text { población total) }\end{array}$ \\
\hline $\begin{array}{l}\text { Students enrolled in primary education (\% per } \\
\text { capita) }\end{array}$ & AN & $\begin{array}{l}\text { Alumnos matriculados en educación primaria (\% de la } \\
\qquad \text { Población total) }\end{array}$ \\
\hline $\begin{array}{l}\text { Students enrolled in secondary education (\% } \\
\text { per capita) }\end{array}$ & AP & $\begin{array}{l}\text { Alumnos matriculados en educación secundaria (\% de } \\
\qquad \text { la Población total) }\end{array}$ \\
\hline $\begin{array}{l}\text { Students enrolled in tertiary education (\% per } \\
\text { capita) }\end{array}$ & AQ & $\begin{array}{l}\text { Estudiantes matriculados en educación terciaria (\% de } \\
\text { la Población total) }\end{array}$ \\
\hline $\begin{array}{l}\text { Theft at the national level, percentage } \\
\text { population total }\end{array}$ & AR & Robo a nivel nacional, tasa por población total. \\
\hline Threatened Species: Invertebrates (number) & AS & Especies Amenazadas: Invertebrados (número) \\
\hline Threatened Species: Plants (number) & AT & Especies Amenazadas: Plantas (número) \\
\hline Threatened Species: Vertebrates (number) & AV & Especies Amenazadas: Vertebrados (número) \\
\hline Total fertility rate (children per women) & AW & Tasa de fecundidad total (hijos por mujer) \\
\hline
\end{tabular}




\begin{tabular}{|c|c|c|}
$\begin{array}{c}\text { Total Sexual Violence at the national level, rate } \\
\text { per } 100,000\end{array}$ & AX & $\begin{array}{c}\text { Violencia Sexual Total a nivel nacional, tasa por } \\
100,000 .\end{array}$ \\
\hline Tourist/visitor arrivals (thousands) & AY & Llegada de turistas / visitantes (miles) \\
\hline Urban population (percent) & AZ & Población urbana (porcentaje) \\
\hline Estimation Population (millions) & BA & $\begin{array}{c}\text { Estimaciones de mitad de año de la población } \\
\text { (millones) }\end{array}$ \\
\hline
\end{tabular}

